\title{
Guillermo Garzón Romero: Un mundo totalmente absurdo
}

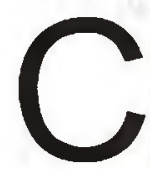
omo ha acontecido con varios artistas a través del tiempo, el lugar de nacimiento y los hechos históricos han marcado las vivencias que luego son proyectadas a sus prácticas artísticas, ligadas a su existencia, a su vida, a sus experiencias. Tal es el caso del artista Guillermo Garzón Romero (Algeciras-Huila, 28 de septiembre de 1949), quien ha colaborado con sus pinturas y dibujos, contenidos en las imágenes de la caratula, contra carátula e ilustraciones de la presente edición de Paideia Surcolombiana.

Como es conocido, la Región Surcolombiana se caracteriza por servir de escenario a los múltiples enfrentamientos ocasionados por los dementes juegos de poder, decretados por los dueños de la guerra. Fenómeno que tiende a permanecer, porque "el conflicto ha sido un fracaso tanto para el Estado, que no ha logrado acabarlo en más de 40 años, como para los grupos en armas, que no han logrado tomarse el poder y se han visto obligados a replegarse en el terreno local, con todas las consecuencias conocidas en términos de degradación de la lucha (rentismo, crimen atroz, narcotráfico, etc.)"

Es como si las probadas estrategias del terror y la barbarie iniciadas con el arcabuz, la espada, la cruz y los despropósitos de la abusiva corona, continuaran hoy con el fusil, la moto sierra y un

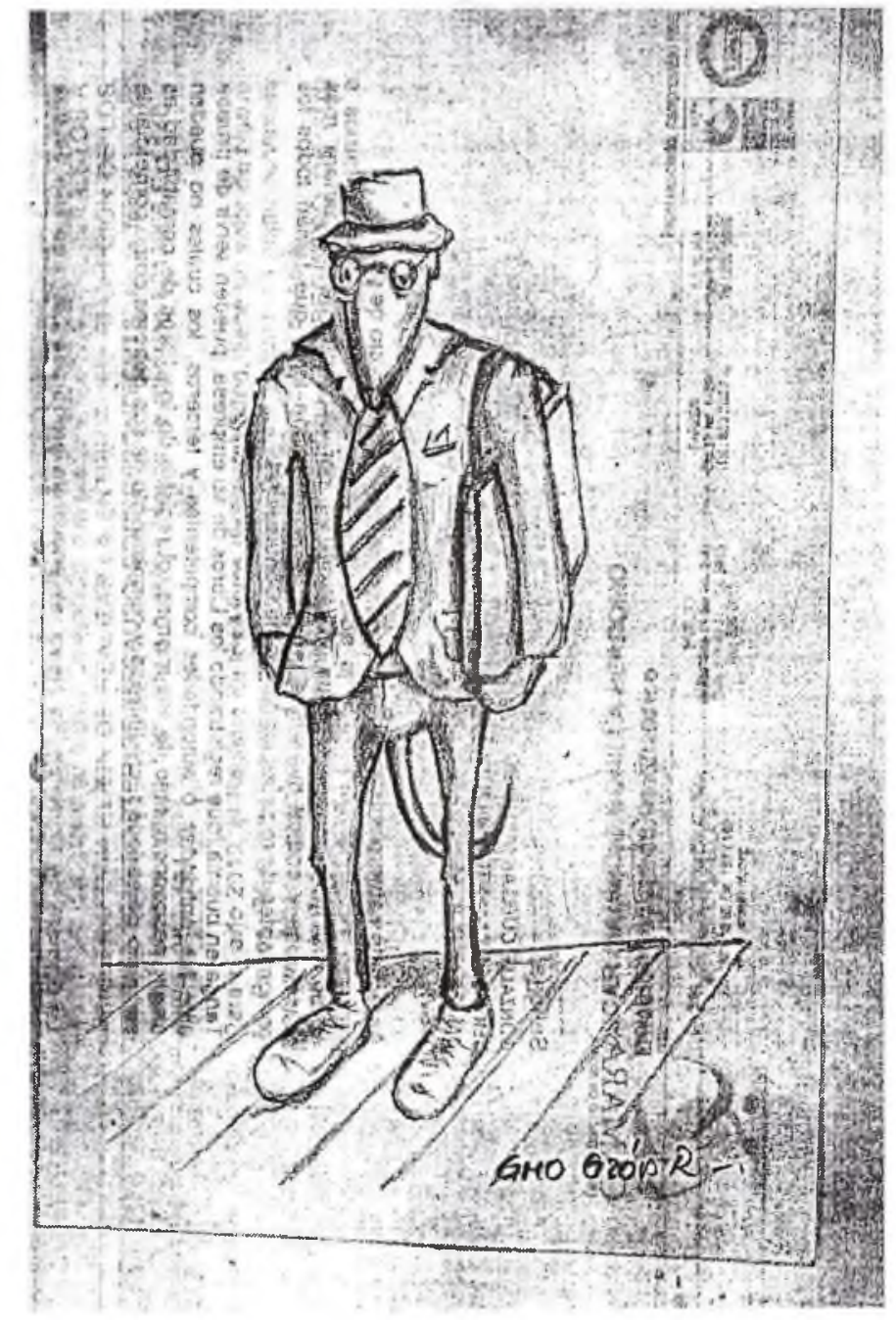

sistema cohonestador para terminar de entregarle a los grupos armados, los narcotraficantes, el hampa organizada, los corruptos de cuello blanco, los dueños del país 


\section{Paneas Surcolombiana 17}

y las transnacionales el patrimonio de la nación. Para ello se asesinan lideres, desaparecen pobladores, reclutan niños, queman viviendas o se desplaza por la fuerza a las comunidades desprotegidas.

Por lo cual, un lugar central en el arte actual de nuestro pais lo ocupa los distintos abordajes de la bárbara guerra fratricida y algunas de sus secuelas; en esta esfera, las obras de los artistas apuntan a señalar el común denominador que vive la población, justificado por el estado permanente del dolor, angustia intensa, desesperación, muerte y duelo.

Desde la propia experiencia, el trabajo de Guillermo Garzón Romero nos habla de los lesivos impactos ocasionados con las aberrantes prácticas de beber la sangre de las víctimas, las desmembraciones realizadas con moto sierras, los hallazgos de innumerables fosas comunes, los falsos positivos y los consecuentes desplazamientos; es decir, representa los crímenes de lesa humanidad y las exacciones cometidos contra el pueblo Surcolombiano.

Para tal efecto, el lenguaje de sus trabajos recurre a las soluciones visuales planteadas tanto por la tradición expresionista como por la surrealista. Mientras con la primera muestra lo crudo del horror a través de la pintura a óleo, con la segunda trata de huir de la realidad con una serie de planteamientos gráficos, que esbozan la enunciación de un mundo totalmente absurdo; tal cual es la realidad de nuestro contexto sociocultural. 